\title{
Solid-Phase Synthesis and Crystallization of Monellin, an Intensely Sweet Protein
}

\author{
Masanori Kohmura, Noriki Nio and Yasuo ARIYoshi \\ Central Research Laboratories, Ajinomoto Co., Inc., \\ 1-l Suzuki-cho, Kawasaki-ku, Kawasaki 210. Japan
}

Received December 27, 1989

\begin{abstract}
Monellin, a sweet protein, consists of two noncovalently associated polypeptide chains, the A chain of 44 amino acid residues and the $B$ chain of 50 residues. Two different primary structures have been reported for each of the $A$ and $B$ chains. The $A$ and $B$ chains corresponding to one of the reported monellin structures were synthesized by the stepwise solid-phase method using the Fmoc strategy in overall yields of $14.1 \%$ and $5.6 \%$, respectively. The characterization of the synthetic peptides by HPLC, FAB-MS, amino acid analysis and sequencing fully supported the expected structures. The individual synthetic $A$ and $B$ chains were not sweet. Combination of the two chains, and subsequent HPLC purification gave monellin in a yield of $53.9 \%$. The synthetic monellin had a distinct, lingering sweet taste (4000 times sweeter than sucrose) and was crystallized by a vapor diffusion method. The synthetic product was identical to natural monellin by HPLC, but not by tryptic mapping. These results indicate that the reported structure for monellin differs slightly from that of natural monellin.
\end{abstract}

Monellin, an intensely sweet protein, has been isolated from the fruit of the West African plant, Dioscoreophyllum cumminsii (Stapf) Diels, and is about 3000 times sweeter than sucrose. ${ }^{1,2)}$ Monellin consists of two noncovalently associated polypeptide chains, the $A$ chain of 44 amino acid residues and the $B$ chain of 50 residues. $^{3-5}$ ) Its native conformation is important for the sweet taste..$^{3,6-8)}$ The individual $\mathrm{A}$ and $\mathrm{B}$ chains are not sweet, and careful recombination of the two chains has elicited the sweet taste. ${ }^{3)}$ Recently, its Xray crystal structure has also been determined. ${ }^{9)}$

In an attempt to deduce the mode of interaction between sweet peptides and their receptor, we have synthesized a number of sweet peptides. ${ }^{10)}$ In connection with this study, we undertook the synthesis of monellin.

Two different primary structures have been reported for each of the $\mathrm{A}$ and $\mathrm{B}$ chains. $^{3-5}$ ) Thus, there are four possible combinations for constructing the monellin structure. It seemed that this discrepancy in structure arose from the different identification procedures for phenylthiohydantoin amino acids after Edman degradation of the protein. It was reasoned that identification by liquid chromatography ${ }^{4)}$ would give more accurate results than that by gas chromatography. ${ }^{3)} \mathrm{We}$, therefore, first synthesized the structure proposed by Frank and Zuber. ${ }^{4)}$

The peptide synthesis was performed manually by the stepwise solid-phase method with a semi-automated peptide synthesizer (for the A chain) and with a manual shaker in a reaction vessel (for the B chain), using the baselabile fluoren-9-ylmethoxycarbonyl (Fmoc) group $^{11)}$ for protecting the $\alpha$-amino group, and such acid-labile groups as the tert-butyl $\left(\mathrm{Bu}^{t}\right)$ for the hydroxyl and carboxyl groups, the 4methoxy-2,3,6-trimethylbenzenesulfonyl $(\mathrm{Mtr})^{12)}$ for the guanidino group of $\mathrm{Arg}$, the tert-butyloxycarbonyl (Boc) for the $\varepsilon$-amino group of Lys, and the 4,4'-dimethoxybenzhydryl $(\mathrm{Mbh})^{13)}$ for the amide groups of Asn and Gln. The sulfhydryl group of Cys was blocked with the p-methoxybenzyl (MBzl) group, which could be cleaved with trimethylsilylbromide (TMSBr) in trifluoroacetic acid (TFA). ${ }^{14)}$ A preliminary synthesis of the $B$ chain revealed that the sulfur atom of the me- 


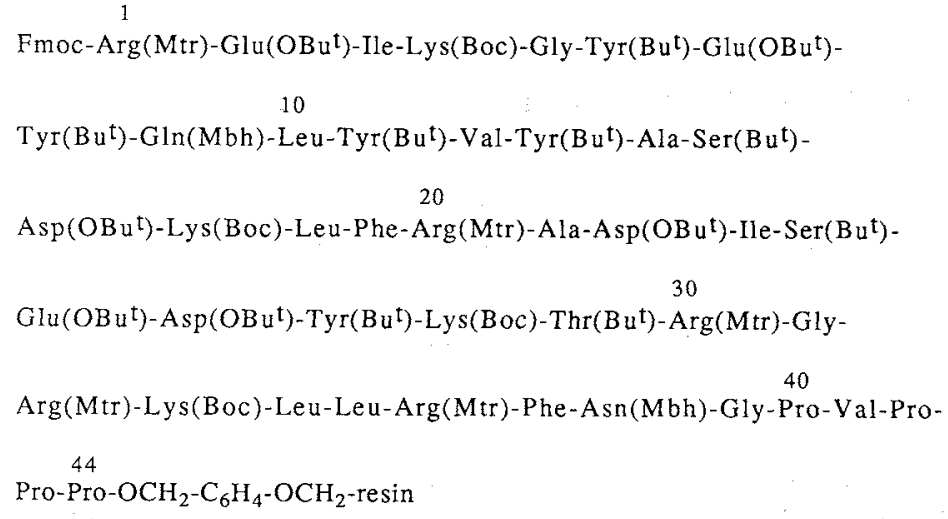

B chain

Fig. 1. Protection Scheme for the Stepwise Solid-Phase Synthesis of Monellin.

thionine residue was susceptible to air oxidation to form the corresponding sulfoxide. Contamination of the synthetic $B$ chain by the sulfoxide form made the elution profile of high-performance liquid chromatography (HPLC) complicated. Therefore, the sulfide group of the methionine residue was protected as the sulfoxide group, which could be reduced with TMSBr in TFA to the sulfide group. ${ }^{14}$ ) The peptide was assembled on a $p$-alkoxybenzyl alcohol resin, ${ }^{15)}$ which could be cleaved from the desired peptide under mildly acidic conditions.

The protection scheme for the stepwise solid-phase synthesis of monellin is shown in Fig. 1. The Fmoc group was removed with $50 \%$ or $20 \%$ piperidine in $N, N-$ dimethylformamide (DMF). In our previous report, ${ }^{16)}$ treatment of an Fmoc-HN-CHR$\mathrm{CO}-\mathrm{Pro}-\mathrm{OCH}_{2}-\mathrm{C}_{6} \mathrm{H}_{4}-\mathrm{OCH}_{2}$-resin with piperidine resulted in elimination of the dipeptide from the resin support, and removal of the Fmoc group of such peptides has been successfully accomplished by the use of $0.2 \%$ piperidine in DMF and prolonged reaction times. ${ }^{16)}$ Analogous attempts to remove the Fmoc group from Fmoc-Pro-Pro- $\mathrm{OCH}_{2}-$ $\mathrm{C}_{6} \mathrm{H}_{4}-\mathrm{OCH}_{2}$-resin with various concentrations of piperidine in DMF were unsuccessful. Therefore, the synthesis of Fmoc-Pro-Pro-Pro$\mathrm{OCH}_{2}-\mathrm{C}_{6} \mathrm{H}_{4}-\mathrm{OCH}_{2}$-resin was carried out by coupling Fmoc-Pro-Pro-OH with H-Pro$\mathrm{OCH}_{2}-\mathrm{C}_{6} \mathrm{H}_{4}-\mathrm{OCH}_{2}$-resin. Elongation of the peptide chain was carried out by the conven- 
tional dicyclohexylcarbodiimide (DCC)/1hydroxybezotriazole (HOBt) method ${ }^{17)}$ in $\mathrm{CH}_{2} \mathrm{Cl}_{2}$-DMF. Deprotection of the Fmoc group and the coupling reaction were monitored by the Kaiser test. ${ }^{18)}$ In the synthesis of the A chain, the monitoring data indicated that, for most residues, repeated coupling was necessary for quantitative incorporation, and for some residues, a second deprotection was necessary. When the deprotection was insufficient, the treatment with piperidine was repeated until a clear positive Kaiser test was obtained. When the coupling was incomplete, the reaction was repeated until a negative Kaiser test was obtained. When the coupling was incomplete even by repeated coupling, the symmetrical anhydride method was used. If no further improvements could be made by these procedures, the "capping" procedure with acetic anhydride-pyridine was applied to eliminate the formation of the deletion peptides. In the synthesis of the B chain, the symmetrical anhydride method or the DCC/HOBt method in $N$-methyl-2-pyrrolidone (NMP) was employed for the amino acid residues whose coupling had been found to be difficult in a preliminary synthesis of the $B$ chain.

After cleavage of the peptides from the solid support, the peptides were purified to homogeneity by preparative reversed-phase HPLC on a $\mathrm{C}_{18}$ column. Deprotection and purification of the synthetic A chain were accomplished in the usual manner. The peptide-resin was treated with $\mathrm{CH}_{2} \mathrm{Cl}_{2}$-anisole-thiophenolTFA, and the resulting peptide was further treated with thiophenol-thioanisole-TFA (Fig. 2A), and then purified by preparative HPLC to give the pure A chain (Fig. 2B) in an overall yield of $14.1 \%$ based on the amine content of the starting amino acid resin. On the other hand, many difficulties arose in the synthesis of the B chain. After extensive efforts, synthesis of the B chain was accomplished. In the deprotection step, the peptide-resin was treated with $\mathrm{CH}_{2} \mathrm{Cl}_{2}$-anisole $m$-cresol-1,2ethanedithiol-TFA. The resulting peptide was further treated with thioanisole- $m$-cresol-1,2ethanedithiol-TFA and then with TMSBr, and finally precipitated with ether (Fig. 3A). The crude B chain was purified by HPLC to give the pure B chain (Fig. 3B) in an overall yield of $5.6 \%$ based on the amine content of the starting resin.

The purity of each peptide obtained in this way was further confirmed by analytical HPLC, fast atom bombardment mass spectrometry (FAB-MS), quantitative amino acid analysis after hydrolysis in constant-boiling $\mathrm{HCl}$ containing $1 \%$ phenol at $110^{\circ} \mathrm{C}$ for $24 \mathrm{hr}$ (for the $\mathrm{A}$ chain), and 24 and $96 \mathrm{hr}$ (for the B chain), and

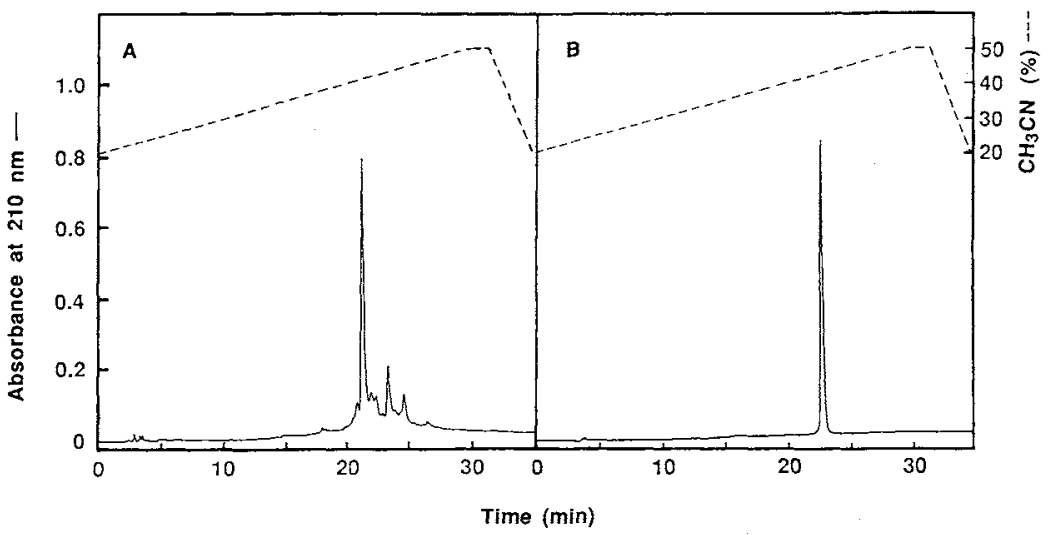

Fig. 2. HPLC on an Analytical Reversed-Phase Inertsil ODS $5 \mu \mathrm{m} \mathrm{C} \mathrm{C}_{18}$ Column $(4.6 \times 250 \mathrm{~mm})$ of the Synthetic A Chain Directly after Deprotection and Cleavage (A), and after Purification (B).

The solvent systems were $0.05 \%$ aqueous TFA (A) and acetonitrile containing $0.05 \%$ TFA (B). The sample was eluted with a linear gradient of $20 \% \mathrm{~B}$ to $50 \% \mathrm{~B}$ obtained in $30 \mathrm{~min}$ at a flow rate of $1.0 \mathrm{ml} / \mathrm{min}$. The elution profile was monitored at $210 \mathrm{~nm}$. 


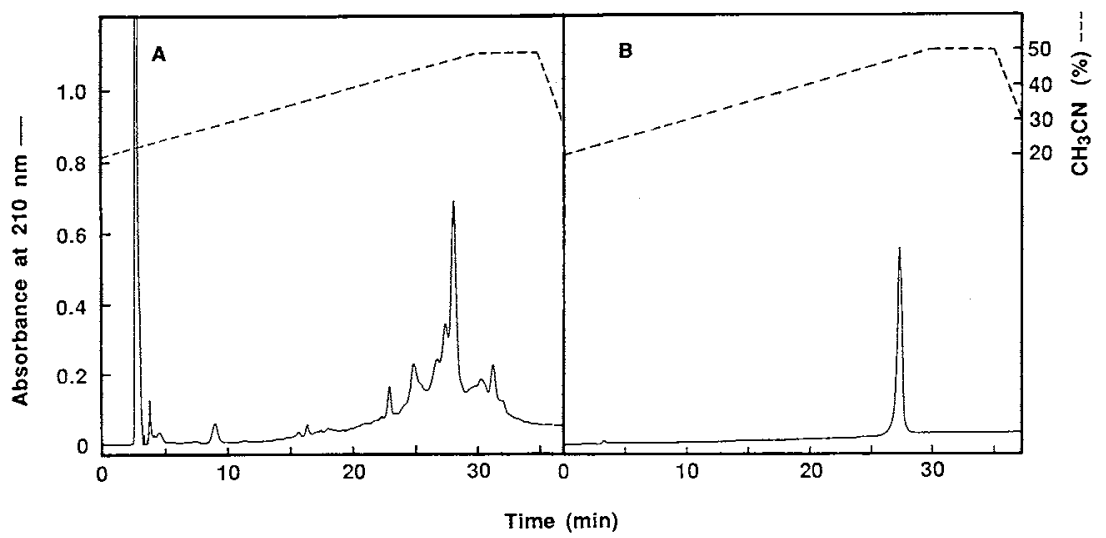

Fig. 3. HPLC on an Analytical Reversed-Phase Inertsil ODS-2 $5 \mu \mathrm{m} \mathrm{C}{ }_{18}$ Column $(4.6 \times 250 \mathrm{~mm})$ of the Synthetic B Chain Directly after Deprotection and Cleavage (A), and after Purification (B).

The sample was eluted with a linear gradient of $20 \% \mathrm{~B}$ to $50 \% \mathrm{~B}$ obtained in $30 \mathrm{~min}$ at a flow rate of $1.0 \mathrm{ml} / \mathrm{min}$, and then with $50 \%$ B for 5 min employing the solvent systems as those used in Fig. 2.

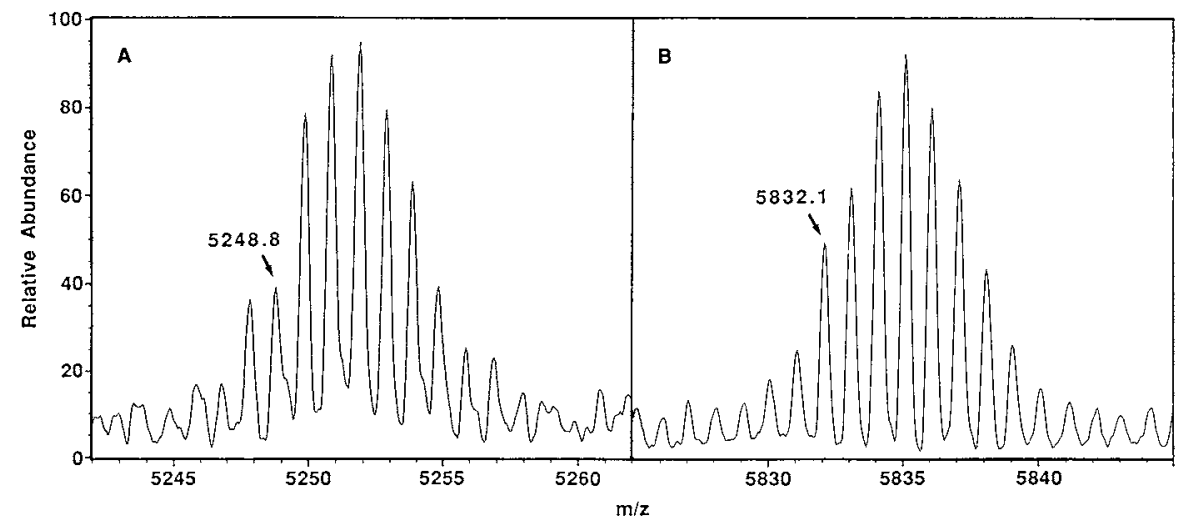

Fig. 4. FAB Mass Spectra of the Synthetic A (A) and B (B) Chains.

sequence analysis by an automatic Edman degradation method. HPLC analysis of each peptide gave satisfactory results (Figs. $2 B$ and 3B). An FAB-mass spectrometric analysis of the A chain gave a protonated monoisotopic molecular ion at $m / z 5248.8$ for a calculated value of $m / z$ 5248:8 (Fig. 4A). Similarly, the observed value for the B chain was $m / z 5832.1$ vs. a calculated value of $m / z 5832.0$ (Fig. 4B). For these spectra, there was no evidence of any impurities, and the observed isotopic distributions were in good agreement with the patterns calculated from the elemental compositions. An amino acid analysis of each peptide gave the expected values (see the experimental section). The Ile-Ile peptide bond was rel- atively resistant to cleavage, the ratio obtained for this amino acid being consistently low after $24 \mathrm{hr}$, whereas after $96 \mathrm{hr}$ the value reached the expected ratio. Sequencing of the synthetic A and B chains was carried out on an automated sequencer, using the intact peptides and their tryptic peptides, and the results fully supported the expected sequences.

The individual synthetic $A$ and $B$ chains were not sweet. Combination of the $\mathrm{A}$ and $\mathrm{B}$ chains (Fig. 5A), and subsequent HPLC purification gave monellin in a yield of $53.9 \%$ (Fig. 5B). As can be seen in Fig. 5A, simply by mixing the $A$ and $B$ chains $(1: 1, w / w)$, the natural sweet conformation ${ }^{9)}$ was almost completely formed. The A and B chains were eluted at 


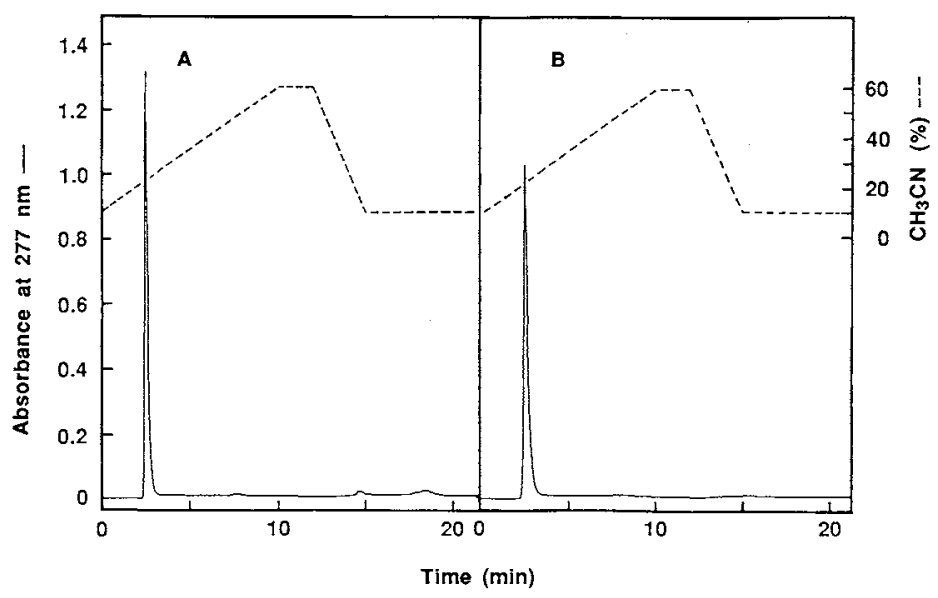

Fig. 5. HPLC on a TSKgel Phenyl-5PW Column $(7.5 \times 75 \mathrm{~mm})$ of the Synthetic Monellin (after 20 hr, A) Prepared by Mixing the $A$ and $B$ Chains ( $1: 1, w / w)$, and after Purification (B).

The solvent systems were $0.1 \%$ aqueous TFA (A) and acetonitrile containing $0.1 \%$ TFA (B). The sample was eluted with a linear gradient of $10 \% \mathrm{~B}$ to $60 \% \mathrm{~B}$ obtained in $10 \mathrm{~min}$ at a flow rate of $1.0 \mathrm{ml} / \mathrm{min}$. The elution profile was monitored at $277 \mathrm{~nm}$.

6.07 and $7.42 \mathrm{~min}$, respectively, when they were separately analyzed by HPLC under the same conditions as those described in Fig. 5. When a $1: 1$ mixture of the $A$ and $B$ chains was analyzed, only one peak appeared at $2.65 \mathrm{~min}$. The synthetic monellin had a distinct, lingering sweet taste (about 4000 times sweeter than sucrose), and its amino acid analysis gave a satisfactory result. It was interesting that, after tasting a $0.6 \%$ sucrose solution, the sweetness intensity of a solution of the synthetic monellin was significantly enhanced. Moreover, after rinsing the tongue repeatedly with a highly diluted tasteless solution of the synthetic monellin, the solution itself tasted sweet. A similar phenomenon has been observed for thaumatin, a sweet protein. ${ }^{19)}$

Crystallization was carried out by the "hanging drop" vapor diffusion method, in which the synthetic monellin was dissolved in a mixture of aqueous polyethylene glycol and phosphate buffer, and equilibrated with aqueous polyethylene glycol '(Fig. 6).

It is known that approximately $10 \%$ of the A chain of natural monellin carries an extra phenylalanine at the N-terminus. ${ }^{4)}$ Thus, a comparison of the synthetic product with natural monellin was performed after separat-

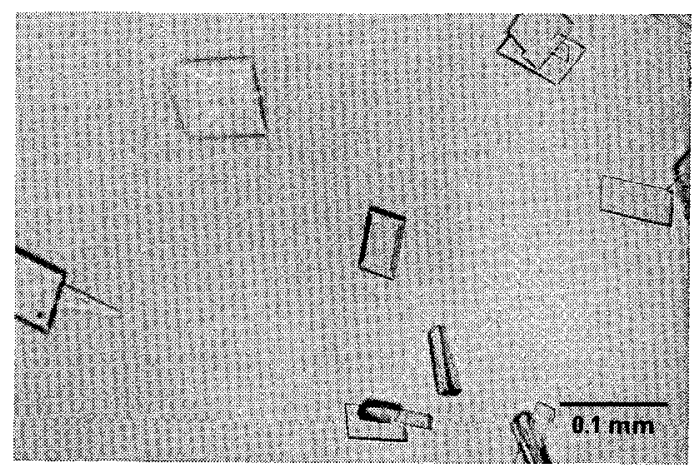

Fig. 6. Crystals of the Synthetic Monellin Grown by the "Hanging Drop" Vapor Diffusion Method and Photographed under a Polarized Microscope within a Crystallizing Well.

ing these peptide chains. Separation of the A, phenylalanyl A, and B chains of natural monellin was readily accomplished by HPLC. Recombination of the separated A chain (44 residues) with the separated $B$ chain gave "natural monellin". The synthetic monellin was identical to the reconstituted monellin by HPLC, but not by tryptic mapping (data not shown). Therefore, a comparison was made between the individual chains. The synthetic A chain was identical to the separated natural A chain (44 amino acid residues) by tryptic map- 


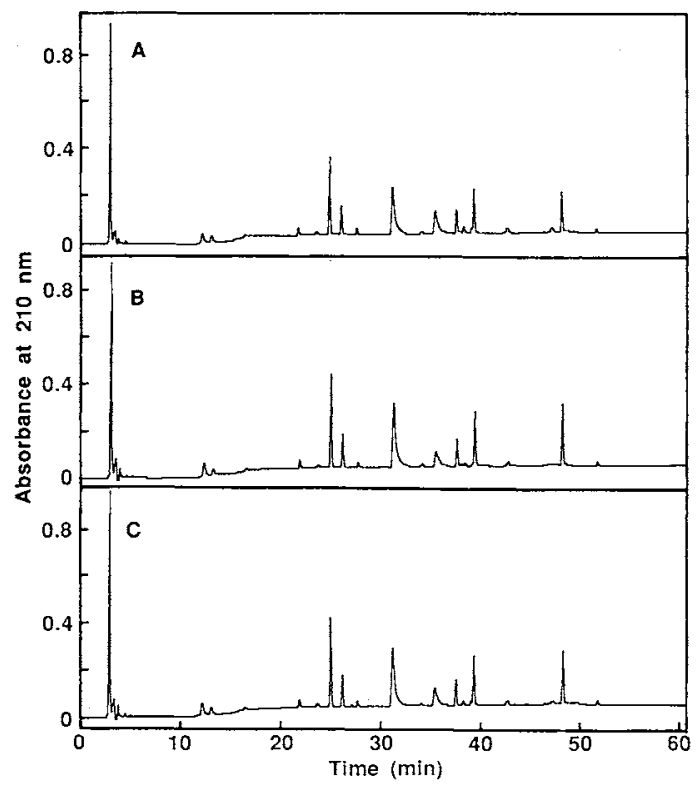

Fig. 7. HPLC on an Analytical Reversed-Phase Inertsil ODS-2 $5 \mu \mathrm{m} \quad \mathrm{C}_{18}$ Column $(4.6 \times 250 \mathrm{~mm})$ of Tryptic Digests of the Synthetic A (A) and Natural A (B) Chains, and Their Mixture (C).

The solvent systems were $0.1 \%$ aqueous TFA (A) and acetonitrile containing $0.1 \%$ TFA (B). The sample was eluted with a linear gradient of $5 \% \mathrm{~B}$ to $50 \% \mathrm{~B}$ obtained in $60 \mathrm{~min}$ at a flow rate of $1.0 \mathrm{ml} / \mathrm{min}$. The elution profile was monitored at $210 \mathrm{~nm}$.

ping (Fig. 7), but the synthetic B chain was not identical to the separated natural B chain by tryptic mapping (Fig. 8). These results indicate that the reported structure for the $\mathrm{B}$ chain ${ }^{4)}$ differs slightly from that of the natural $B$ chain. We, therefore, determined the primary structure of natural monellin, and the result will be soon described elsewhere. Synthesis of the structures reported by other groups $^{3,5)}$ are now in progress.

\section{Experimental}

The protected amino acids and amino acid-resins were obtained from Bachem Feinchemikalien AG (Switzerland) and Kokusan Chemical Works Ltd. Trypsin (type XIII, bovine pancreas, Tos-Phe- $\mathrm{CH}_{2} \mathrm{Cl}$-treated) was purchased from Sigma Chemical Co. Fmoc-Pro-Pro-OH and monellin were obtained by courtesy of Dr. S. Ikeda of Kokusan Chemical Works Ltd. and Dr. J. G. Brand of Monell Chemical Senses Center, respectively. Fmoc-MetO-OH was

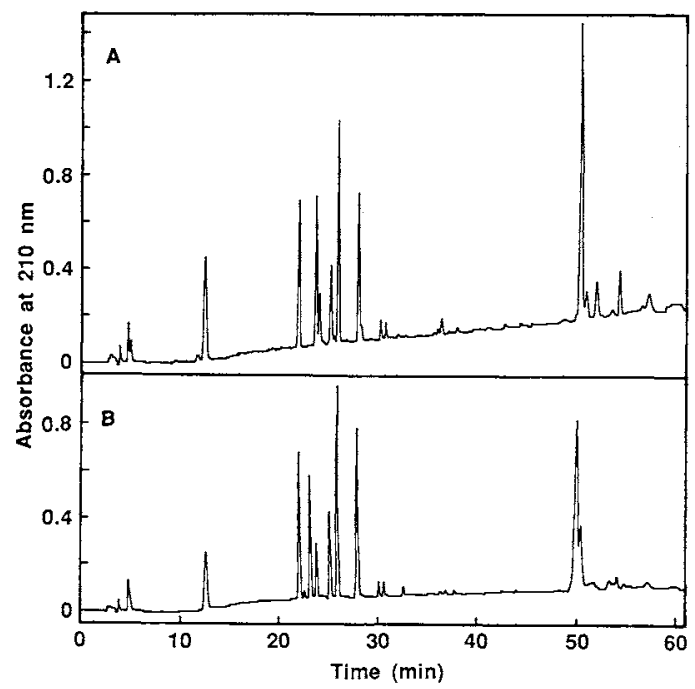

Fig. 8. Analytical HPLC of Tryptic Digests of the Synthetic B (A) and Natural B (B) Chains under the Conditions Described in Fig. 7.

synthesized according to the method described for the synthesis of $\mathrm{Z}(\mathrm{OMe})-\mathrm{MetO}-\mathrm{OH}^{20)}$ All solvent were of reagent or HPLC grade. The peptide synthesis was carried out manually by the stepwise solid-phase method with a semiautomated peptide synthesizer, Labortec SP 640 (for the $A$ chain), and with a manual shaker in a reaction vessel (for the B chain). Coupling and deprotection performed at room temperature unless otherwise stated. HPLC was carried out on a Waters M600 instrument under linear gradient conditions $\left[\mathrm{C}_{18}\right.$ reversed-phase columns: Inertsil ODS, $5 \mu \mathrm{m}$, Gasukuro Kogyo, $4.6 \times 250 \mathrm{~mm}$ (for analytical HPLC of the A chain); Inertsil ODS-2, $5 \mu \mathrm{m}$ Gasukuro Kogyo, $4.6 \times 250 \mathrm{~mm}$ (for analytical HPLC of the $B$ chain and of tryptic peptides; and Inertsil ODS, $5 \mu \mathrm{m}$, Gasukuro Kogyo, $16.2 \times 250 \mathrm{~mm}$ (for preparative HPLC of the A and B chains), UV detection at $210 \mathrm{~nm}$; TSKgel Phenyl-5PW, Tosoh, $7.5 \times 75 \mathrm{~mm}$ (for monellin), UV detection at $277 \mathrm{~nm}$ ]. Peptide hydrolyses were performed in constant-boiling $\mathrm{HCl}$ containing $1 \%$ phenol at $110^{\circ} \mathrm{C}$ for $24 \mathrm{hr}$ (for the A chain), and 24 and $96 \mathrm{hr}$ (for the $\mathrm{B}$ chain and monellin) in a sealed ampule under high vacuum. Quantitative amino acid analyses were carried out on a Hitachi 835 amino acid analyzer. FAB-mass spectra were taken on a JEOL JMS HX110/HX110 tandem mass spectrometer. Sequencing of the synthetic A and $\mathrm{B}$ chains was performed on a $470 \mathrm{~A}$ automated protein sequencer from Applied Biosystems (U.S.A.). Abbreviations follow the recommendations of the IUPACIUB Commission on Biochemical Nomenclature in Eur. J. Biochem., 138, 9 (1984).

Synthesis of the A chain. Fmoc-Pro- $\mathrm{OCH}_{2}-\mathrm{C}_{6} \mathrm{H}_{4}-\mathrm{OCH}_{2}-$ resin $(0.53 \mathrm{mmol} / \mathrm{g}, 200 \mathrm{mg}, 0.106 \mathrm{mmol})$ was suspended in 
DMF $(15 \mathrm{ml})$ in a $50-\mathrm{ml}$ reaction vessel and shaken for 15 min to swell the resin. The peptide synthesis was carried out by the DCC/HOBt method in which 3 equivalents $(0.318 \mathrm{mmol})$ of the amino acid derivatives, 3.3 equivalents $(0.350 \mathrm{mmol})$ of DCC, and 3.6 equivalents $(0.382 \mathrm{mmol})$ of HOBt were used.

The following synthesis cycle was used.

(a) Fmoc cleavage: (i) shaking in DMF ( $15 \mathrm{ml}$ ) for $1 \mathrm{~min}$ to swell the resin; (ii) repeated treatment $(3+10 \mathrm{~min})$ with $50 \%$ piperidine in DMF $(15 \mathrm{ml})$ while shaking.

(b) Washing: (i) DMF ( $15 \mathrm{ml}$, four times, $30 \mathrm{sec}$ each); (ii) isopropanol (15 ml, twice, $1 \mathrm{~min}$ each); (iii) cleavage was monitored with the Kaiser test. If the cleavage was incomplete, procedures (a) and (b) were repeated until a positive Kaiser test was obtained.

(c) Coupling: (i) shaking in DMF (15 ml, twice, $1 \mathrm{~min}$ each) to swell the resin; (ii) an appropriate Fmoc-amino acid derivative $(0.318 \mathrm{mmol})$ and $\mathrm{HOBt}(0.382 \mathrm{mmol})$ were dissolved in a mixture $(10 \mathrm{ml})$ of $\mathrm{CH}_{2} \mathrm{Cl}_{2}$ and DMF $(9: 1$; $\mathrm{v} / \mathrm{v})$, and a $1 \mathrm{M}$ DCC solution $\left(0.35 \mathrm{ml}\right.$ in $\left.\mathrm{CH}_{2} \mathrm{Cl}_{2}\right)$ was added; (iii) shaking for $70 \mathrm{~min}$.

(d) Washing: (i) DMF ( $15 \mathrm{ml}$, once, $1 \mathrm{~min}$ ); (ii) isopropanol ( $15 \mathrm{ml}$, twice, $1 \mathrm{~min}$ each); (iii) coupling was monitored with the Kaiser test. If the result was positive, procedures (c) and (d) were repeated. When the coupling was incomplete, even after the repeated coupling, the peptideresin was treated with 20 equivalents of acetic anhydridepyridine to terminate the elongation of the unreacted peptide chain (the "capping" procedure).

In the foregoing synthesis cycle, several modifications were made for complete incorporation and deprotection. Fmoc-Pro-Pro-Pro-OCH${ }_{2}-\mathrm{C}_{6} \mathrm{H}_{4}-\mathrm{OCH}_{2}$-resin was prepared by coupling Fmoc-Pro-Pro-OH (0.318 mmol) with $\mathrm{H}-\mathrm{Pro}-\mathrm{OCH}_{2}-\mathrm{C}_{6} \mathrm{H}_{4}-\mathrm{OCH}_{2}$-resin, because treating Fmoc-Pro-Pro- $\mathrm{OCH}_{2}-\mathrm{C}_{6} \mathrm{H}_{4}-\mathrm{OCH}_{2}$-resin with piperidine resulted in elimination of the dipeptide from the resin support. For residues 41, 31, 28, 26, 16, 11 and 5, the Fmoc cleavage procedure was performed twice. For residues $42-40,37,32,27-24,22,20,17,16,12,9-4,2$ and 1 , the coupling procedure was performed twice; for residue 23 , the coupling procedure was carried out three times. For residue 3 , after coupling by the $\mathrm{DCC} / \mathrm{HOBt}$ method, the symmetrical anhydride method was applied, in which the symmetrical anhydride of Fmoc-Ile-OH was prepared in an ice-bath for $20 \mathrm{~min}$ with 6 equivalents $(225 \mathrm{mg}$, $0.636 \mathrm{mmol})$ of Fmoc-Ile-OH and 3 equivalents $(0.318 \mathrm{ml}$, $0.318 \mathrm{mmol}$ ) of a $1 \mathrm{M} \mathrm{DCC}$ solution (in $\mathrm{CH}_{2} \mathrm{Cl}_{2}$ ).

After the last coupling step, the Fmoc group was cleaved according to procedures (a) and (b). The peptide-resin was washed with $\mathrm{CH}_{2} \mathrm{Cl}_{2}$ ( $15 \mathrm{ml}$, three times, $1 \mathrm{~min}$ each), and then treated with $\mathrm{CH}_{2} \mathrm{Cl}_{2}$-anisole-thiophenol-TFA $(12.3: 2.0: 0.7: 20 ; \mathrm{v} / \mathrm{v}, 35 \mathrm{ml})$ for $2 \mathrm{hr}$ at room temperature. After filtration, the filtrate was concentrated to a small volume under reduced pressure at a bath temperature of $50^{\circ} \mathrm{C}$. The peptide was precipitated with ether, filtered off, and dried. Yield, $518 \mathrm{mg}$. The peptide thus obtained was further treated with thiophenol-thioanisole--
TFA $(0.5: 1.5: 13.5 ; \mathrm{v} / \mathrm{v}, 15.5 \mathrm{ml})$ for $5 \mathrm{hr}$ at room temperature. A sufficient amount of ether was added to the reaction mixture, and the resulting precipitate was collected by filtration and dried. Yield, $485 \mathrm{mg}$. The HPLC elution profile of this peptide is shown in Fig. 2A. The crude peptide (about $40 \mathrm{mg}$ ) was dissolved in $2 \mathrm{ml}$ of $20 \%$ acetonitrile containing $0.05 \%$ TFA, loaded onto a preparative HPLC column (Inertsil ODS, $16.2 \times 250 \mathrm{~mm}$ ), and purified by using $0.05 \%$ aqueous TFA and acetonitrile containing $0.05 \%$ TFA under a linear gradient condition (from $20 \%$ to $50 \%$ acetonitrile in $20 \mathrm{~min}$ at a flow rate of $9 \mathrm{ml} / \mathrm{min}$ ). The procedure was repeated to purify the whole amount of the peptide $(485 \mathrm{mg})$, the fractions being checked by analytical HPLC (Fig. 2B). The pure fractions were collected, pooled, concentrated to a small volume under reduced pressure, and lyophilized to give the pure A chain (Fig. 2B). Overall yield, $78.6 \mathrm{mg}(14.1 \%)$.

Amino acid analysis (hydrolyzed for $24 \mathrm{hr}$ ), numbers in parentheses being theoretical values: Asp, 4.00 (4); Thr, 1.01 (1); Ser, 1.81 (2); Glu, 3.96 (4); Pro, 4.03 (4); Gly, 3.02 (3); Ala, 2.03 (2); Val, 1.97 (2); Ile, 1.90 (2); Leu, 4.01 (4); Tyr, 4.84 (5); Phe, 2.01 (2); Lys, 3.95 (4); Arg, 4.99 (5).

FAB-MS: $m / z 5248.8(\mathrm{M}+\mathrm{H})^{+}$; calculated value, $m / z$ $5248.8(\mathrm{M}+\mathrm{H})^{+}$.

Sequencing: Residues $\mathrm{Arg}^{1}$ to $\mathrm{Phe}^{37}$ of the synthetic A chain were determined by automatic sequencing of the intact $A$ chain. The rest of the sequence was determined by automatic sequencing of a tryptic peptide. The tryptic digestion was carried on a sample $(0.20 \mathrm{mg})$ of the synthetic A chain, which was dissolved in $8 \mathrm{M}$ urea $(25.0 \mu \mathrm{l})$, and then $0.2 \mathrm{M}$ ammonium acetate buffer $(65.0 \mu \mathrm{l}, \mathrm{pH} 8.0)$ was added to this solution. The mixture was treated with 10.0 $\mu \mathrm{l}$ of a trypsin-containing solution $(0.8 \mathrm{mg} / \mathrm{ml})$ for $16 \mathrm{hr}$ at $37^{\circ} \mathrm{C}$. After repeated lyophilization (twice) to remove the ammonium acetate, the digest was dissolved in $50.0 \mu \mathrm{l}$ of $5 \%$ acetonitrile containing $0.1 \%$ TFA. The resulting solution $(25.0 \mu 1)$ was loaded onto an analytical HPLC column, and eluted with $0.1 \%$ aqueous TFA and acetonitrile containing $0: 1 \%$ TFA under a linear gradient condition (from 5\% to $50 \%$ acetonitrile in $60 \mathrm{~min}$ at a flow rate of $1 \mathrm{ml} / \mathrm{min}$ with detection at $210 \mathrm{~nm}$ ). The peaks were separately collected, pooled and lyophilized. The amino acid composition of each tryptic peptide was determined (data not shown), the amino acid composition of a peak eluted at 31.4 min by HPLC agreeing with that of the C-terminal octapeptide. Its sequence was determined by automatic sequencing to be Phe-Asn-Gly-Pro-ValPro-Pro-Pro (37-44).

Tryptic mapping: A tryptic digest $(5.0 \mu 1)$ of the synthetic A chain was analyzed by HPLC under the same conditions as those just described. A parallel experiment was run on the natural A chain (see details for the A chain later). The HPLC patterns are shown in Fig. 7.

Separation of the $A$ and $B$ chains of natural monellin. Monellin $(7.65 \mathrm{mg})$ was dissolved in $500 \mu \mathrm{l}$ of $20 \%$ acetonitrile containing $0.05 \%$ TFA and loaded onto a prepara- 
tive HPLC column. The sample was eluted with $0.05 \%$ aqueous TFA and acetonitrile containing $0.05 \%$ TFA under a linear gradient condition (from $20 \%$ to $50 \%$ acetonitrile in $30 \mathrm{~min}$ at a flow rate of $9 \mathrm{ml} / \mathrm{min}$ ). The peaks eluted at 22.38 and $29.68 \mathrm{~min}$ were separately collected, pooled and lyophilized to give $3.20 \mathrm{mg}$ of the $\mathrm{A}$ chain and $2.61 \mathrm{mg}$ of the $\mathbf{B}$ chain, respectively. Details will be described elsewhere with the determination of the primary structure of monellin in this series.

Synthesis of the B chain. Fmoc-Glu $\left(\mathrm{OBu}^{t}\right)-\mathrm{OCH}_{2}-\mathrm{C}_{6} \mathrm{H}_{4}-$ $\mathrm{OCH}_{2}$-resin $(0.61 \mathrm{mmol} / \mathrm{g}, 328 \mathrm{mg}, 0.200 \mathrm{mmol})$ was suspended in DMF $(10 \mathrm{ml})$ in a $25-\mathrm{ml}$ reaction vessel and shaken for $15 \mathrm{~min}$ to swell the resin. The synthesis cycle was virtually the same as the method used for the synthesis of the A chain. Taking into consideration the result obtained by a preliminary synthesis of the B chain, Fmoc cleavage and coupling steps, however, were partly modified as next described.

(a) Fmoc cleavage: (i) shaking in DMF (10 ml) for $1 \mathrm{~min}$ to swell the resin; (ii) repeated treatment with $50 \%$ piperidine in DMF $(10 \mathrm{ml})$ while shaking; the reaction period was $3+10 \mathrm{~min}$ for residues 50 and $48-41,3+15 \mathrm{~min}$ for residues $39-25$ and $23-15$, and $3+20 \mathrm{~min}$ for residues 40 , 24 and 14-2; the Fmoc group of Asn(Mbh) at position 49 was cleaved by repeated treatment $(3+10 \mathrm{~min})$ with $20 \%$ piperidine in DMF $(10 \mathrm{ml})$.

(b) Washing: (i) DMF ( $10 \mathrm{ml}$, four times, $30 \mathrm{sec}$ each); (ii) isopropanol (10 $\mathrm{ml}$, twice, $1 \mathrm{~min}$ each); (iii) cleavage was monitored with the Kaiser test. If the cleavage was incomplete, procedures (a) and (b) were repeated.

(c) Coupling: residues 49-40, 36-34 and 32 were coupled by the DCC/HOBt method in which $1 \mathrm{M} \mathrm{DCC}(0.66 \mathrm{ml}$ in $\mathrm{CH}_{2} \mathrm{Cl}_{2}$ ) was added to a solution of an appropiate Fmoc-amino acid derivative $(0.600 \mathrm{mmol})$ and $\mathrm{HOBt}$ $(0.720 \mathrm{mmol})$ in a mixture $(7 \mathrm{ml})$ of $\mathrm{CH}_{2} \mathrm{Cl}_{2}$ and DMF $(9: 1 ; \mathrm{v} / \mathrm{v})$, and the mixture was shaken for $90 \mathrm{~min}$ at room temperature. Residues $39-37,33,31,12-10$ and $8-2$ were coupled by the symmetrical anhydride method, in which anhydrides of Fmoc-amino acid derivatives were prepared by the reaction of an appropriate Fmoc-amino acid derivative $(0.800 \mathrm{mmol})$ with $1 \mathrm{M} \mathrm{DCC}\left(0.40 \mathrm{ml}\right.$ in $\left.\mathrm{CH}_{2} \mathrm{Cl}_{2}\right)$ in a mixture of DMF $(3.5 \mathrm{ml})$ and $\mathrm{CH}_{2} \mathrm{Cl}_{2}(3.5 \mathrm{ml})$ in an icebath for $15 \mathrm{~min}$. Coupling was performed for $90 \mathrm{~min}$. For residues $39,33,31$ and 5, each coupling was performed for $4 \mathrm{hr}$, and the Kaiser test data for each indicated that a second coupling was necessary for quantitative incorporation. The second coupling was carried out by the DCC/ HOBt method, in which an appropriate Fmoc-amino acid derivative $(0.600 \mathrm{mmol})$ and $\mathrm{HOBt}(0.720 \mathrm{mmol})$ were treated with $1 \mathrm{M} \mathrm{DCC}\left(0.66 \mathrm{ml}\right.$ in $\left.\mathrm{CH}_{2} \mathrm{Cl}_{2}\right)$ in NMP (7 $\mathrm{ml})$ while shaking for $2 \mathrm{hr}$ and then kept standing overnight. Residues $30-13$ and 9 were coupled by the DCC/ HOBt method, in which an appropriate Fmoc-amino acid derivative $(0.600 \mathrm{mmol})$ and $\mathrm{HOBt}(0.720 \mathrm{mmol})$ were treated with $1 \mathrm{M} \mathrm{DCC}\left(0.66 \mathrm{ml}\right.$ in $\left.\mathrm{CH}_{2} \mathrm{Cl}_{2}\right)$ in NMP $(7 \mathrm{ml})$ while shaking for $3 \mathrm{hr}$. (d) Washing: (i) DMF (10 ml, once, $1 \mathrm{~min})$; (ii) isopropanol (10 ml, twice, $1 \mathrm{~min}$ each); (iii) coupling was monitored with the Kaiser test. If the result was positive, procedure (c) was repeated as already described.

Finally, Boc-Gly-OH $(0.600 \mathrm{mmol})$ was coupled by the DCC/HOBt method ( $1 \mathrm{M} \mathrm{DCC}$ in $\mathrm{CH}_{2} \mathrm{Cl}_{2}, 0.66 \mathrm{ml} / \mathrm{HOBt}$, $0.720 \mathrm{mmol}$ in NMP, $7 \mathrm{ml}$ ) while shaking for $3 \mathrm{hr}$, and then washed according to procedure (d).

After the last coupling step, the peptide-resin was washed successively with DMF ( $10 \mathrm{ml}$, twice, I min each) and isopropanol ( $10 \mathrm{ml}$, four times, $30 \mathrm{sec}$ each), and dried, weighing $1.60 \mathrm{~g}$. The peptide-resin $(1.60 \mathrm{~g})$ was treated with $\mathrm{CH}_{2} \mathrm{Cl}_{2}$-anisole- $m$-cresol-1,2-ethanedithiolTFA $(12.3: 2.0: 0.5: 0.2: 20 ; \mathrm{v} / \mathrm{v}, 35 \mathrm{ml})$ while stirring for $2 \mathrm{hr}$ at room temperature. After filtration, the filtrate was concentrated to a small volume under reduced pressure. The peptide was precipitated with ether, collected by filtration, and dried. Yield, $1.04 \mathrm{~g}$. The crude peptide was dissolved in a mixture of thioanisole- $m$-cresol-1,2-ethanedithiol-TFA $(3.52: 0.75: 0.30: 21.47 ; \mathrm{v} / \mathrm{v}, 26.04 \mathrm{ml})$ and stirred for $10 \mathrm{~min}$ at room temperature, and then cooled in an ice-bath. To this ice-cooled, stirred mixture was added dropwisely $\mathrm{TMSBr}(3.96 \mathrm{ml})$, stirring being continued for $4 \mathrm{hr}$ while cooling. A sufficient amount of ether was added to the reaction mixture, and then the resulting precipitate was collected by filtration and dried. The crude peptide thus obtained was suspended in water $(20 \mathrm{ml})$, and 2-mercaptoethanol $(400 \mu \mathrm{l})$ was added to the suspension, which was then adjusted to $\mathrm{pH} 8$ with triethylamine while stirring and cooling in an ice-bath. To this solution was added $1 \mathrm{~m}$ ammonium fluoride $(800 \mu \mathrm{l})$. The mixture was stirred for $30 \mathrm{~min}$ while cooling and then adjusted to $\mathrm{pH} 5$ with acetic acid. The resulting precipitate was collected by filtration and dried, and then dissolved in TFA $(10 \mathrm{ml})$ and filtered. The HPLC profile of the filtrate is shown in Fig. 3A. The filtrate (300-325 $\mu$ l) was loaded onto a preparative HPLC column and purified under a linear gradient condition (from 20\% to $50 \%$ acetonitrile containing $0.05 \%$ TFA in $30 \mathrm{~min}$ at a flow rate of $9 \mathrm{ml} / \mathrm{min}$ ). The procedure was repeated 31 times to purify the whole amount of the peptide. The fractions of the main peak thus obtained were collected, concentrated under reduced pressure to a small volume, lyophilized, and finally dried over $\mathrm{NaOH}$ pellets in vacuo, yielding $195.10 \mathrm{mg}$ of the $\mathrm{B}$ chain. This compound was dissolved in $66.7 \%$ TFA $(1.2 \mathrm{ml})$ and further purified by preparative HPLC under the same conditions as those already described to give $65.16 \mathrm{mg}$ ( $5.6 \%$ overall yield) of the pure B chain (Fig. 3B).

Amino acid analysis (hydrolyzed for $24 \mathrm{hr}$, with $96 \mathrm{hr}$ for the Ile-Ile bond*), numbers in parentheses being theoretical values: Asp, 6.07 (6); Thr, 2.86 (3); Glu, 7.80 (8); Pro, 2.11 (2); Gly, 5.23 (5); Ala, 1.07 (1); Val, 1.85 (2); Met, 0.87 (1); Ile*, 5.62 (6); Leu, 2.08 (2); Tyr, 2.05 (2); Phe, 3.03 (3); Lys, 4.88 (5); Arg, 2.02 (2). Trp and Cys were not determined.

FAB-MS: $m / z 5832.1(\mathrm{M}+\mathrm{H})^{+}$; calculated value, $m / z$ 
$5832.0(\mathrm{M}+\mathrm{H})^{+}$

Sequencing: Residues Gly ${ }^{1}$ to $\mathrm{Lys}^{44}$ of the synthetic B chain were determined by automatic sequencing of the intact $B$ chain. The rest of the sequence was determined by automatic sequencing of a tryptic peptide. The tryptic digestion was carried on a sample $(0.20 \mathrm{mg})$ of the synthetic B chain, which was dissolved in $88.8 \mu \mathrm{l}$ of $0.2 \mathrm{M}$ ammonium acetate buffer $(\mathrm{pH} 8.0)$ and treated with $11.2 \mu \mathrm{l}$ of a trypsin-containing solution $(0.8 \mathrm{mg} / \mathrm{ml})$ for $8 \mathrm{hr}$ at $37^{\circ} \mathrm{C}$. HPLC was worked up as described for the sequencing of the A chain, the peaks being separately collected, pooled and lyophilized. The amino acid composition of each peptide was determined (data not shown), the amino acid composition of a peak eluted at $23.5 \mathrm{~min}$ agreeing with that of the $C$-terminal heptapeptide. Its sequence was determined by automatic sequencing to be Lys-Thr-Ile-TyrGlu-Asn-Glu (44-50).

Tryptic mapping: The tryptic digestion was carried out as already described, and the HPLC pattern is shown in Fig. 8A. A parallel experiment was run on the natural $B$ chain, and the HPLC pattern is shown in Fig. 8B.

Combination of the synthetic monellin $A$ and $B$ chains. The synthetic A chain (4.88 $\mathrm{mg}$ ) was dissolved in $0.1 \%$ acetic acid $(610 \mu \mathrm{l})$, from which $600 \mu \mathrm{l}$ was taken out. The synthetic B chain $(4.80 \mathrm{mg})$ was dissolved in this solution $(600 \mu \mathrm{l})$, and the resulting mixture was stirred for $1 \mathrm{~min}$ with a mixer under an atmosphere of nitrogen, and then kept standing at room temperature for $20 \mathrm{hr}$. The HPLC elution profile of the mixture is shown in Fig. 5A. The mixture $(100 \mu 1)$ was loaded onto a TSKgel Phenyl-5PW column $(7.5 \times 75 \mathrm{~mm})$ and purified under a linear gradient condition (Fig. 5). The procedure was repeated 6 times to purify the whole amount of the mixture, and the fractions of the main peak were collected, pooled and lyophilized. The protein thus obtained was dissolved in water $(400 \mu \mathrm{l})$ and shaken at room temperature for $2 \mathrm{hr}$. After that, the solution was checked by HPLC under the same conditions as those used in the purification of the protein (Fig. 5B). The solution containing the protein was lyophilized to give pure monellin, which was dried over $\mathrm{NaOH}$ pellets in vacuo. Yield, $4.92 \mathrm{mg}(53.9 \%)$.

Amino acid analysis (hydrolyzed for $24 \mathrm{hr}$, with $96 \mathrm{hr}$ for the Ile-Ile bond*), numbers in parentheses being theoretical values: Asp, 10.00 (10); Thr, 4.00 (4); Ser, 2.00 (2); Glu, 11.64 (12); Pro, 6.18 (6); Gly, 7.82 (8); Ala, 2.91 (3); Val, 4.00 (4); Met, 1.27 (1); Ile*, 7.63 (8); Leu, 6.00 (6); Tyr, 7.09 (7); Phe, 5.09 (5); Lys, 8.73 (9); Arg, 6.98 (7). Trp and Cys were not determined.

Crystallization of the synthetic monellin. Crystallization was carried out by a combination of the methods described by Tomlinson and $\mathrm{Kim},{ }^{21)}$ and by Wlodawer and Hodgson, ${ }^{22)}$ using the "hanging-drop" vapor diffusion method. A wide variety of crystallization conditions was surveyed by using a monellin solution $(4 \mathrm{mg} / \mathrm{ml})$ and various concentrations of a precipitant solution (aqueous polyethylene glycol) at $4^{\circ} \mathrm{C}$ and at room temperature. The dishes used were Linbro tissue culture trays with 24 separate wells (Flow Laboratories Inc., U.S.A.). Each well was filled with a precipitant solution $(1 \mathrm{ml})$, and a protein solution $(10 \mu \mathrm{l})$ was placed on a clean, siliconized cover glass with a pipette. The rim of each well was coated with silicone grease, and the cover glass was put on the well in such a way that a droplet faced the solution. A typical run involved a solution containing $4 \mathrm{mg} / \mathrm{ml}$ monellin in a $14 \%(\mathrm{w} / \mathrm{w})$ solution of polyethylene glycol and $10 \mathrm{~mm}$ phosphate buffer at $\mathrm{pH} 7.2$ being equilibrated with a $28 \%(\mathrm{w} / \mathrm{w})$ solution of polyethylene glycol and $10 \mathrm{~mm}$ phosphate buffer at $4^{\circ} \mathrm{C}$. Crystals appeared after 5 days and developed into well-shaped crystals after 2 weeks at $4^{\circ} \mathrm{C}$ (Fig. 6).

Sweetness evaluation. The sweetness value of the synthetic monellin was organoleptically determined by a panel of five untrained people. The evaluation was carried out at concentrations near the threshold to avoid confusion arising from the persistent lingering sweet taste of monellin. Thus, the sweetness evaluation was carried out by matching a threshold concentration of the synthetic monellin with that $(0.6 \%, \mathrm{w} / \mathrm{v})$ of sucrose. The synthetic monellin $(1.20 \mathrm{mg})$ was dissolved in water $(20 \mathrm{ml})$, this concentration corresponding to a $0.006 \%(\mathrm{w} / \mathrm{v})$ monellin solution. This solution was diluted with water to several dilutions ( 30,40 , and 45 times), and the sweetness intensity of each was compared with that of the $0.6 \%$ sucrose solution. The solution from the 30 -fold dilution was sweeter than the $0.6 \%$ sucrose solution. The sweetness intensity of the 40 -fold dilution was almost equal to that of $0.6 \%$ sucrose, and the 45 -fold dilution was judged faintly sweet or not sweet. These results indicated that the synthetic monellin was about 4000 times sweeter than sucrose, although no attempt was made to quantitate the sweetness potency. It was found that, after tasting a $0.6 \%$ sucrose solution, the sweetness intensity of the 45 -fold diluted solution was significantly enhanced. Moreover, after rinsing the tongue repeatedly with the 45 -fold diluted solution, the solution itself tasted sweet. Thus, the $0.006 \%$ monellin solution was further diluted with water to several dilutions $(50,60,70$, 80,90 and 100 times), and the tongue was repeatedly rinsed with these solutions. A sweet taste was observed even for the 80 -fold diluted solution, this corresponding to 8000 times that of sucrose in sweetness potency.

Acknowledgments. We thank Dr. J. G Brand for sending us the sample of monellin, Dr. S. Ikeda for providing us with Fmoc-Pro-Pro-OH, Dr. S. Nagashima for his helpful advice on crystallization of the synthetic monellin, Dr. K. Hirayama, Ms. S. Akashi and Ms. M. Furuya for measurements of FAB-MS, and Mr. S. Ozawa and Mr. T. Seino for amino acid analyses. 


\section{References}

1) J. A. Morris and R. H. Cagan, Biochim. Biophys. Acta, 261, 114 (1972).

2) H. van der Wel, FEBS Lett., 21, 88 (1972).

3) Z. Bohak and S.-L. Li, Biochim. Biophys. Acta, 427, 153 (1976).

4) G. Frank and H. Zuber, Hoppe-Seyler's Z. Physiol. Chem., 357, 585 (1976).

5) G. Hudson and K. Biemann, Biochem. Biophys. Res. Commun., 71, 212 (1976).

6) R. H. Cagan and J. A. Morris, Proc. Soc. Exp. Biol. Med., 152, 635 (1976).

7) R. W. Morris, R. H. Cagan, R. E. Martenson and G. Deibler, Proc. Soc. Exp. Biol. Med., 157, 194 (1978)

8) J. G. Brand, R. H. Cagan and D. L. Bayley, Proc. Soc. Exp. Biol. Med., 179, 76 (1985).

9) C. Ogata, M. Hatada, G. Tomlinson, W.-C. Shin and S.-H. Kim, Nature, 328, 739 (1987)

10) Y. Ariyoshi, Y. Hasegawa and N. Nio, Peptide Chemistry, 1986, 251 (1987). Also see references cited therein.

11) L. A. Carpino and G. Y. Han, J. Am. Chem. Soc., 92 , $5748(1970)$.
12) M. Wakimasu, C. Kitada and M. Fujino, Chem. Pharm. Bull., 30, 2766 (1982).

13) W. König and R. Geiger, Chem. Ber., 103, 2041 (1970).

14) H. Yajima, N. Fujii, S. Funakoshi, T. Watanabe, E. Murayama and A. Otaka, Tetrahedron, 44, 805 (1988).

15) S.-S. Wang, J. Am. Chem. Soc., 95, 1328 (1973).

16) M. Kohmura, N. Nio, K. Kubo, Y. Minoshima, E. Munekata and Y. Ariyoshi, Agric. Biol. Chem., 53, 2107 (1989).

17) W. König and R. Geiger, Chem. Ber., 103, 788 (1970).

18) E. Kaiser, R. L. Colescott, C. D. Bossinger and P. I. Cook, Anal. Biochem., 34, 595 (1970).

19) H. van der Wel and K. Loeve, Eur. J. Biochem., 31, 221 (1972).

20) N. Fujii, T. Sasaki, S. Funakoshi, H. Irie and H. Yajima, Chem. Pharm. Bull., 26, 650 (1978).

21) G. E. Tomlinson and S.-H. Kim, J. Biol. Chem., 256, $12476(1981)$.

22) A. Wlodawer and K. O. Hodgson, Proc. Natl. Acad. Sci. U.S.A., 72, 398 (1975). 